\title{
Improving the Memory through Singing Method of Children Ages 5 - 6 Years in Kindergarten Insan Pandhega
}

\author{
Meta Br Ginting \\ Universitas Sari Mutiara Indonesia, Indonesia \\ metamunthe31@gmail.com
}

\begin{abstract}
The problem in this study was that $48 \%$ of children had difficulty remembering their parents 'full names, $72 \%$ of children did not remember the full address of their residence, and $100 \%$ of children did not remember their parents' telephone numbers. This study aims to develop children's memory of their important personal identity through singing methods. This type of research is classroom action research by model Kemmis and Mc. Taggart. This research was carried out in the Kindergarten InsanPandhega with a total subject of 25 children, consisting of 11 girls and 14 boys. The object of this research is the singing method. The technique of collecting children's memory data is done by nonformal test techniques, namely writing important information that describes the child's memory. Furthermore, the data is processed to obtain a memory percentage value of children categorized into: undeveloped, developing, developing well, developing very well. This study was successful if the memory of children who reached the criteria of developing well and developing very well reached more than $75 \%$. The study was conducted in two cycles. Overall, the average memory of children in the first cycle which is in the well-developed and developing category is $36 \%$. Whereas in the second cycle the average memory of children in the well-developed and very well-developed category was $80 \%$.
\end{abstract}

Keywords:

Memory; Singing Method

\section{INTRODUCTION}

In the process of learning, the functions of memory have a very important role. Memory plays a role in every psychological function. Learning requires memory. Every thought happens by relying on memory. Learning also provides new knowledge in memory. Information is given in various forms such as visual, auditory, text or multimedia, tend to be "summarized" to outline when stored in memory (Carter \& Seifert. 2014:277)

Clark (in Sujiono 2010: 49) states that when children are born their brains have brought the potential contained in 100-200 billion cells of neurons stored in the brain. Each neuron cell is ready to be developed to process several trillion information. During the child's development period, the brain continues to changes in accordance with stimulation received through all the five senses, this will also affect the level of intelligence, personality, and quality of life of a child. That is, children have the ability to remember or store information obtained.

In the process of learning memory functions have a very important role. If the memory is good, the academic achievement of the child will also be good otherwise if the memory is not good it will have 
an impact on the child's achievement which can lead to a low self-confidence. To achieve good memory, the optimal brain integration process is needed. There are various ways to optimize memory including learning, playing, and the use of learning methods that support the workings of the brain (Sarwono. 2009: 115).

Cognitive development is closely related to remembering information received by the brain's ability to rely heavily on memory through the process of building, interpreting, storing, changing and retrieving information. Information enters memory through an encoding process that occurs automatically (unconsciously) or consciously (with effort) that requires attention, or focuses mentally on certain information. (Carter \& Seifert, 2014: 279).Learning in early childhood requires the ability to remember. Remembering information that is useful for safety and honing children's life skills. One of the information that is important to remember by children is knowledge of their information, such as: the name of the parent (nuclear family), the telephone number of the parent and the address of the residence in full. The child's memory of this important information is one of the basic safety measures proposed by Bharadia Raksha (2013: 86).

Interviews with researchers with early childhood children in the Pandhega Elementary School, out of 46 children there were 12 people or $26 \%$ of children who remembered their parents' names in full, and 3 children or $6.5 \%$ of children who know their home address well and no child (0\%) knows the telephone number of one of their parents meanwhile these memories of this information are important to safe children.Santrock (2007: 288) stated that children's memory increases rapidly after passing infancy. The long-term memory of preschoolers seems erratic, but young children are able to remember a lot of information as long as they get the right signals and evidence. So it can be concluded that in fact children have the potential to remember important information in themselves.

Talking about memory, just like talking about brain function. Adree (in Sujiono 2010: 49) states that in essence the brain determines behavior, the brain that determines personality, and the brain stores memories of experience. The law of brain development states: "If the brain is given stimulation through stimuli that enter through the five senses, the memory will continue to work. Conversely, if the brain is not stimulated, the memory will be destroyed. (Sujiono.2010: 50) In this regard, brain stimulation in early childhood refers to the work process of the brain, which senses everything in the environment through seeing, smelling, tasting, touching or listening. The senses then go through the brain fibers into electric waves and are stored in the brain into memory or memory which can then be reappeared as the original.

The results of brain research conducted by Paul McLean (in Megawangi et al. 2010: 25) explain that one part of the brain, the limbic system has several principles, namely; (1) The limbic system is very influential in the human learning process. This system controls memory abilities, human learning 
abilities, and responds to all information received by the human senses; (2) These system controls every information that enters, and selects only valuable information. Valuable information will be stored, while valuable information will be forgotten. That's why the brain's limbic system determines the formation of long-term memory; (3) The brain does not pay attention to all information that is not interesting, boring, and does not cause emotion; (4) The aspects of physiology, emotion and memory have important implications for the learning process, namely a pleasant learning atmosphere, involving all sensory aspects of human beings (five senses), relevant and contextual, and most importantly the learning process must provide a sense of happiness; (5) Fun learning atmosphere can provide positive emotional experiences, so as to maximize children's attention and memory.

Frank Wood, argues that music is the first language of the brain, and singing is the earliest type of music. Music including singing has an effect on the brain by way of intellectual and emotional stimulation. The results of the Abdolmanafi et al (2014) study entitled "The Effect of Background Music on Vocabulary Recall and Retention of Children Learning A ForeingLangunge" concluded that the experimental group that received treatment with the singing method had a better ability to remember and save. vocabulary from the control group. The results of the study are in line with Ludke's article, et al. (2013) entitled "Singging can facilitate foreign language learning" concluding that listening and singing can facilitate in terms of remembering words to speak foreign language phrases.

In line with the results of the above research, Risaldy (2015: 88) says that the singing method is one method that is very popular with early childhood. Hidayat (2014: 4.27) states that the singing method is an approach to learning that is actually able to make children happy and happy. Children are directed to psychological situations and conditions to build a happy soul, love to enjoy beauty, develop feelings through words and tones, and rhythmic expressions that beautify the learning atmosphere. So that the singing method can be applied in building children's memory. Harianti (2008: 17) states: "Information that is combined with the rhythm will be more remembered by the brain, because one of the principles of memory is rhythmic". In other words when entering elements of a song or rhythm into an information will make the information easier to remember. It can be concluded that the singing method is one method that can affect children's memory. Because singing is an activity that can create joy and cheerful atmosphere.

Based on the background described, the formulation of the problem in this study is "Does the Singing Method Affect the Memory of Children Aged 5-6 Years in InsanPandhega of Kindergarten Medan Helvetia?". This study aims to prove the influence of the singing method on the ability to remember children. As well as an effort to develop the ability to remember children of important information.

\section{THEORETICAL PERSPECTIVES}




\section{Memory}

Remembering is the ability to reproduce information contained in memory (Hapsari 2016: 215). Furthermore, Femi Olivia (2007: 55) argues that memory is the ability to remember the subject matter obtained after the learning period has passed.Tan\& Seng (2005: 230) states: "Memory encompasses the encoding, storage, of and retrieval of information from the previous experience, and is critical to learning". This opinion is supported by Carter Colleen (2014: 276) who states that memory is a consequence that remains in the mind about our experiences in the world. Based on some of the opinions above, the researchers concluded that memory or what is usually referred to as memory, namely the ability to store, process and revive information absorbed by the brain.

According to Semiawan (2017: 35), the part of the human brain consists of the brainstem and cerebellum, the limbic system (mammalian brain) and the neocortex, each of which is independent but interrelated in its function. The limbic system, often referred to as the mammalian brain, has a brain component called the amygdala, hippocampus, thalamus and hupothalamus. The basic part of the brain in learning and maintaining new information is a small area whose shape resembles a sea horse called the hypocampus field (from the Greek hippocampus meaning seahorse). The hippocampus acts when someone actively learns something new. Even after information is well mastered, the storage is in a different location, another part of the brain called the celebral cortex. So, someone who is reminded of the things that have happened a few years ago got them back from the cerebral cortex. (Mc.Khann. Albert 2010: 32).The hippocampus as part of the limbic system is in the left hemisphere and the right brain. This structure manages all information and sends it to memory. This hippocampus is very susceptible to stress hormones called cortisol. While the role of the amygdala, which is the smallest almond-shaped structure in the medial temporal lobe, plays a role with both positive and negative emotions. However, besides that the amygdala also influences emotionally in learning that involves someone's cognition, especially in the aspect of memory. Even interesting and fun lessons will be longer and more memorable. Also important decisions can not be separated fromthe role of this emotional brain (Semiawan, 2017: 44.45).

According to Wijanarko and Setiawati (1998: 35), Amygdala is part of the ganglia ward and part of the limbic system which has a role in processing memory, emotional reactions, and decision making with functions of forming and storing memories related to emotional events and regulating consolidation. memory in other brain regions. Meanwhile some researchers have considered that the hippocampus is part of the memory system of the medial temporal lobe responsible for general declarative memory. The hippocampus functions are: a. forming new memories related to events that have been experienced, be it episodic or autobiographical memory by detecting new events, places and stimuli; b. role in forming spatial memory and navigation. So it can be concluded that from the three parts of the 
human brain, more memory is processed and stored in the limbic system, the amygdala and hippocampus.

Based on the study above, the researcher concluded that memory is a work process of the brain, where memory / information is stored properly when implanted with excitement through an impressive activity in the child.In this study the memory that will be tested is the child's memory of the full address of the house, memory about the full address of the school, full name of nuclear family members and memory of self-identity.

\section{Singing Method}

The singing method is one method that is very popular with early childhood (Risaldy 2015: 88). Singing gives children fun, fun and fills their day with songs. Furthermore, Risaldy (2015: 91) states that through singing activities the learning atmosphere will be more fun, exciting, make children happy, eliminate feelings of sadness, entertain children and be more excited. By singing the potential of the right brain hemisphere can be optimized, so that the messages we give will settle longer in the long-term memory of the child, so the child will always remember the words that he receives. This statement is in line with the opinion of Hidayat (2014: 4. 27) which states that the singing method is a learning approach that is actually able to make children happy and happy. Children are directed at psychological situations and conditions that build a happy soul, love to enjoy beauty, develop a sense of expression through words and funds, and rhythmic which beautifies the learning atmosphere. Satibi
(2006) revealed that singing activities for early childhood cannot be separated from daily activities. In kindergarten singing is an activity that can be integrated in learning and cannot be separated from the daily activities of children in school.

Songs or songs are music (part of music) which are expressions of one's thoughts / feelings through tones and data that contain an idea (idea), are mindful of beauty (Widiastuti (2017: 29). This opinion is in line with Kamtini's expression (in Risaldy 2015: 90), thatsinging is a means of expressing thoughts and feelings, because singing activities are important for children's education besides singing is a fun activity that gives satisfaction to children. Children enjoy almost every type of song, especially those concerning themselves and their days (Seefeldt et al. 2008: 310). From the statement above it can be concluded that singing can be applied as a learning method for early childhood. Learning with the singing method has a strong connection in the learning process of children at an early age, in addition to fostering high motivation, singing also increases focus power optimally. Thus, singing activities can be used as a method of learning (Widyastuti 2016: 72).

Based on the above opinion it can be concluded that the application of the singing method is appropriate to the principle of how the brain works in developing a child's memory. because when a child sings, unwittingly builds a happy, happy soul, enjoys beauty, develops feelings through words and tones, and rhythmic expressions that beautify the learning atmosphere, besides the singing method is 
inseparable from the day-to-day activities of children in school.The application of the singing method according to Risaldy (2015: 40) consists of the following steps:(a) Planning stage: Determination of learning objectives.

Determination of learning methods. (3) Establish learning methods and techniques, and (4) determine learning evaluation.(b) The implementation phase, in the form of implementing what has been planned, which consists of: (1) The initial activity, the teacher introduces the song to be sung together and gives an example of how the song should be sung and gives direction to the applause that accompanies it. (2) Additional activities, children are invited to dramatize songs, for example my two-eye song, which is by making a gesture of pointing to the organs designated in the song lyrics. (3) Development activities, teachers help children to recognize high and low tones with musical instruments, such as pianika.(c) The assessment phase is carried out using observation guidelines to determine the extent to which the child has developed.The application of singing methods in early childhood can be described in the table below.

\section{RESEARCH METHODS}

This research was carried out with a Classroom Action Research approach. The study was conducted collaboratively between classroom teachers and researchers. Collaboration is realized to equalize understanding, agreement on problems, make decisions and give birth to similar actions aimed at improving children's memory. This research was conducted in the Kindergarten of InsanPandhega. The subjects in this study were children who in the age range of 5-6 years with the number of students 25 children consisting of 11 girls and 14 boys who are in one class. The object in this study is children's memory. The research design used in this study is the Kemmis and Mc Taggart model (in Suwarsih Madya, 1994: 25), which includes activities for planning action, acting, observing, reflecting, and designing subsequent actions. The research of Kemmis and Mc Taggart's model can be explained in the form of figure 2 as follows:

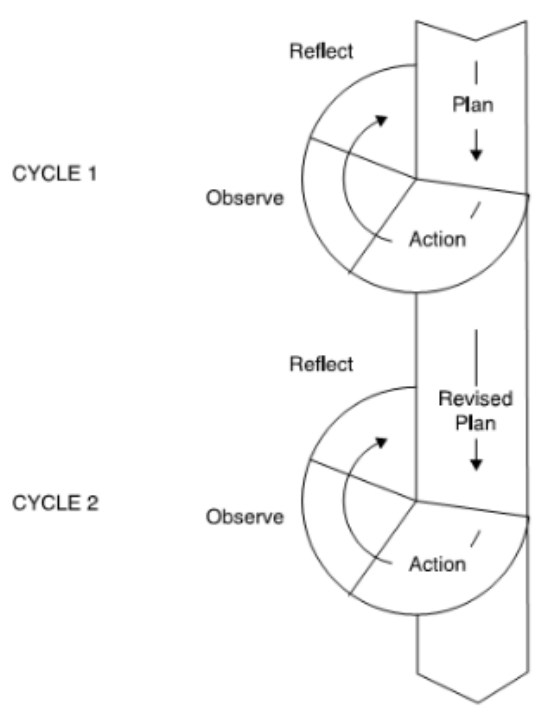

Figure 1. Kemmis and Mc Taggart Model of Classroom Action Research

This classroom action research is carried out in two cycles, each cycle consisting of six meetings. The data collection technique in this study uses interview / question and answer techniques related to children's memory that will be represented non formal test through interview relates to the child's memory that be represented through the skill to communicate it back the information from the song 
not only in oral communication but also in written communication .

The research design was carried out in two cycles, explained as follows:

1. Planning.

a. Researchers and classroom teachers discuss developing a scenario for applying the singing method that contains information related to the full name of the parent, the full address of the child's residence and the personal telephone number of one of the parents of the child. The implementation of the singing method is carried out every day with different memory achievements. Cycle I was carried out for six days.

b. The application of the singing method to improve memory of the full name information of parents is carried out on the first day and second day of cycle I.

c. The application of the singing method to improve memory of the full address information of the child's residence is carried out on the third day and the fourth day of the first cycled.

d. The application of the singing method to improve memory of information on parents' telephone numbers was carried out on the fifth day and the sixth day of cycle I.

e. The researcher prepared a child's memory test instrument

2. Implementation of Action The steps in implementing the singing method actions are as follows:

Table 1.The procedures of applying the singing method.

\begin{tabular}{ll}
\hline \multirow{2}{*}{ STAGES } & \multicolumn{3}{c}{ ACTIVITY } \\
\cline { 2 - 4 } & \multicolumn{3}{c}{ Teacher } \\
\hline PREPARATION & Contents of the song that will be sung by the theme of the song. \\
& teacher. \\
& - The teacher sings the song from by the teacher. \\
& beginning to end \\
& - The teacher sings songs using movements \\
& expressions and movements
\end{tabular}




\begin{tabular}{|c|c|c|}
\hline IMPLEMENTATION & $\begin{array}{l}\text { - The teacher speaks the song lyrics. } \\
\text { - The teacher invites the children to sing } \\
\text { together. } \\
\text { - The teacher invites the children to sing by } \\
\text { muttering. } \\
\text { - The teacher does not participate in } \\
\text { singing but still moves in singing. } \\
\text { - The teacher tells the child to sing with } \\
\text { movement. }\end{array}$ & $\begin{array}{l}\text { - The child follows the lyrics of } \\
\text { the song spoken by the teacher. } \\
\text { - Children sing with the teacher. } \\
\text { - Children join in singing with } \\
\text { mutter. } \\
\text { - Children start singing without } \\
\text { the teacher's guidance using } \\
\text { gestures. } \\
\text { - Children sing with movements } \\
\text { together }\end{array}$ \\
\hline EVALUATION & $\begin{array}{l}\text { - The teacher tells the child to sing solo or } \\
\text { duet in front of the class. } \\
\text { - The teacher asks for information } \\
\text { contained in the song }\end{array}$ & $\begin{array}{l}\text { - Children sing solo or duet in } \\
\text { front of the class } \\
\text { - Children answer questions } \\
\text { according to information } \\
\text { obtained from the song orally } \\
\text { and writtenly. }\end{array}$ \\
\hline
\end{tabular}

3. Observation

Observation is done by observing and recording all the things that occur during the action, which includes the child's behavior, as well as weaknesses and strengths found.

4. Reflection

The researcher reflects after taking action. Researchers and collaborators discuss and evaluate learning activities. The results of the deed test are reviewed then evaluated to perfect the next action. The following are the things done at this stage, namely: (1) Identifying the difficulties and barriers to learning in cycle 1. (2) Improving actions based

Table 2. Grid of Child Memory Test Instruments on the difficulties and obstacles found to carry out the next cycle. In this study the instrument used was a test instrument which was carried out by assessing the writing containing information about the child's full name, the full address of the child's residence and the telephone number of the parent. This research was conducted in even semester, April 2018/2019 academic year. So, children have been able to communicate their memories through writing.

The grid used by researchers in the test guidelines is illustrated in the table below.

\begin{tabular}{lllll}
\hline Variable & Indicator & Description & Skor & Kriteria \\
\hline
\end{tabular}




\begin{tabular}{|c|c|c|c|c|}
\hline \multirow[t]{5}{*}{ Memory } & \multirow[t]{5}{*}{$\begin{array}{l}\text { Children are able to } \\
\text { write down the full } \\
\text { name of one of their } \\
\text { parents }\end{array}$} & $\begin{array}{l}\text { Children are able to: } \\
\text { mention / write their first } \\
\text { name, the middle name of } \\
\text { their parents 'surname } \\
\text { and their parents' } \\
\text { nicknames }\end{array}$ & 3 & $\begin{array}{l}\text { Very } \\
\text { wellDeveloping } \\
\text { (WWD) }\end{array}$ \\
\hline & & $\begin{array}{l}\text { Children are able to write / } \\
\text { write their nickname and } \\
\text { clan name }\end{array}$ & 2 & $\begin{array}{l}\text { Well developed } \\
\text { (WD) }\end{array}$ \\
\hline & & $\begin{array}{l}\text { Children are able to write } \\
\text { down their parents' } \\
\text { nicknames }\end{array}$ & & $\begin{array}{l}\text { Began to develop } \\
\text { (BtD) }\end{array}$ \\
\hline & & & 1 & \\
\hline & & $\begin{array}{l}\text { Children are unable to } \\
\text { write down the names of } \\
\text { their parents }\end{array}$ & 0 & $\begin{array}{l}\text { Undeveloped } \\
\text { (UD) }\end{array}$ \\
\hline & \multirow[t]{3}{*}{$\begin{array}{l}\text { Children are able to } \\
\text { mention / write down } \\
\text { the full address of } \\
\text { their residence }\end{array}$} & $\begin{array}{l}\text { Children are able to } \\
\text { mention / write down the } \\
\text { name of the street, } \\
\text { number, village / city } \\
\text { address of the child. }\end{array}$ & 3 & $\begin{array}{l}\text { Developing very } \\
\text { well (DVW) }\end{array}$ \\
\hline & & $\begin{array}{l}\text { Children are able to write / } \\
\text { write down two child } \\
\text { address statements. }\end{array}$ & 2 & $\begin{array}{l}\text { Well developed } \\
\text { (WD) }\end{array}$ \\
\hline & & $\begin{array}{l}\text { Children are able to write } \\
\text { down one address } \\
\text { statement }\end{array}$ & 1 & $\begin{array}{l}\text { Began to develop } \\
\text { (BtD) }\end{array}$ \\
\hline
\end{tabular}




\begin{tabular}{llll}
\hline & & Children are not able to & Undeveloped \\
& mention / write the & & (UD) \\
& address description & & \\
\hline The child is able to & The child is able to & 3 & Developing very \\
write / write down the & correctly mention / write & well (DVW) \\
telephone number of & down the parent's & \\
his parents & telephone number &
\end{tabular}

$\begin{array}{lll}\text { Children are not able to } & & \text { Well developed } \\ \text { write down / write down a } & 0 & \text { (WD) } \\ \text { parent's telephone } & & \\ \text { number }\end{array}$

\begin{tabular}{lll}
\hline The data obtained were analyzed quantitatively & \\
to determine the improvement of children's memory. & $\mathbf{N P}=\frac{\boldsymbol{R}}{\boldsymbol{B C}} \boldsymbol{X} \mathbf{1 0 0}$ \\
In this study quantitative descriptive analysis & \\
techniques were carried out to analyze data & \\
obtained from the results of memory tests. Analysis & \\
of test results is calculated by looking for the & $\mathrm{NP} \quad:$ The percent value sought or expected \\
percentage average. Overall the value of each cycle & $\mathrm{R} \quad:$ :The raw score obtained by the child \\
is calculated in number. In this study, the singing & $\mathrm{BC} \quad:$ Ideal maximum score from the test in \\
method can be said successful if the average of & question \\
child's memory are in the category of well-develop &
\end{tabular}
and very well-develop that is $75 \%$ or more than it. Data analysis conducted by researchers is the result of research in each cycle. The researcher made a comparison of the percentage of children's values before action and after action with the application of singing methods to improve children's memory. To find out the percentage of children's memory, the data collected was then analyzed using statistics using the formula from NgalimPurwanto (2006: 102), as follows:
After the data is analyzed, it will then be interpreted into five levels. These five levels according to SuharsimiArikunto (2005: 44), namely as follows:

1. If you have $81-100 \%$ suitability: very good

2. If it has a match of $61-80 \%$ : good

3. If you have a suitability of 41-60\%: enough

4. If you have conformity 21-40\%: less

5. If you have a $0-20 \%$ suitability: very less 
The average percentage percentage result is an illustration of the improvement of children's memory. After that, the difference in the percentage of the average pre-action results to cycle 1 is calculated and the difference from the percentage of average Cycle 1 results to cycle 2.

\section{RESULTS DISCUSSION}

\section{Research result}

Pre-cycle data on memory of parents' names. The address of the residence and telephone number of the parent can be illustrated through the table below:

Table 3 Child Memory Pre Cycle Data

\begin{tabular}{lcccc}
\hline \multicolumn{1}{c}{ Memory Indicator } & UD & BtD & WD & WW \\
\hline Parents' Full Names & 12 & 9 & 4 & 0 \\
\hline Percentage & $48 \%$ & $36 \%$ & $16 \%$ & $0 \%$ \\
\hline Full address of Child Residence & 18 & 5 & 2 & 0 \\
\hline Percentage & $72 \%$ & $20 \%$ & $8 \%$ & $0 \%$ \\
\hline Parent's Phone Number & 25 & 0 & 0 & 0 \\
\hline Percentage & $100 \%$ & $0 \%$ & $0 \%$ & $0 \%$ \\
\hline
\end{tabular}

From the data above, it can be explained that the memory of the full name of the master and the complete address of the child's residence in the well developed category is $8 \%$, the undeveloped category is $73 \%$. Whereas the categories of begin to develop are amounted to $19 \%$. Pre-memory of the child's cycle is depicted in the stem digram below.

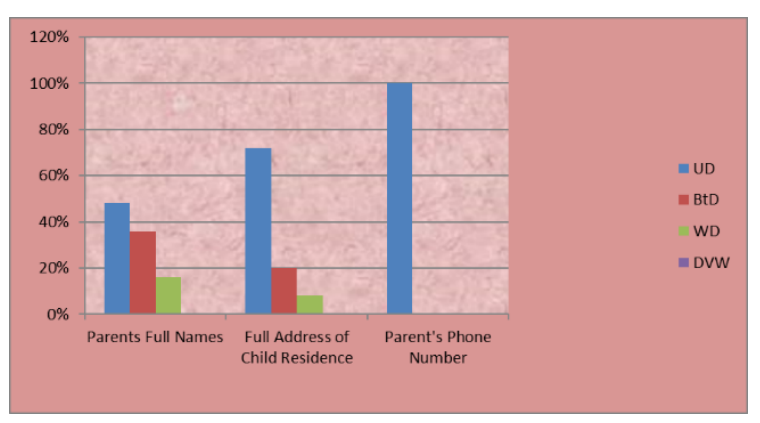

Figure 2. Child's Memory Diagram in Pre Cycle
This diagram illustrates that the highest bar diagram is a category of undeveloped diagrams (UD). So that efforts need to be made in improving children's memory of their parents 'full names, complete residential addresses and parents' telephone numbers through the design of learning by applying the singing method.

\section{Cycle I}

The following is the achievement of the development of children's memory as a result of applying the method of singing in the kindergarten of Insan Pandhega.

Table 4. Child Memory Pre Cycle Data 


\begin{tabular}{|l|c|c|c|c|}
\hline \multicolumn{1}{|c|}{ Memory Indicator } & UD & BtD & WD & DWW \\
\hline Parents' Full Names & 3 & 13 & 6 & 3 \\
\hline Percentage & $12 \%$ & $52 \%$ & $24 \%$ & $12 \%$ \\
\hline Full address of Child Residence & 8 & 11 & 4 & 2 \\
\hline Percentage & $32 \%$ & $44 \%$ & $16 \%$ & $8 \%$ \\
\hline Parent's Phone Number & 14 & 0 & 0 & 11 \\
\hline Percentage & $56 \%$ & $0 \%$ & $0 \%$ & $44 \%$ \\
\hline
\end{tabular}

Through the application of the child's memory singing method to the full name of his parents who reached the well-developed category and developed very well $36 \%$. Memory of the full address of a child's residence with a well-developed category and developing very well reaches $24 \%$. While the child's memory of the telephone numbers of parents who developed with a well-developed category and developed very well reached $44 \%$. The improvement of child's memory in cycle 1 was drawn by the following diagram.

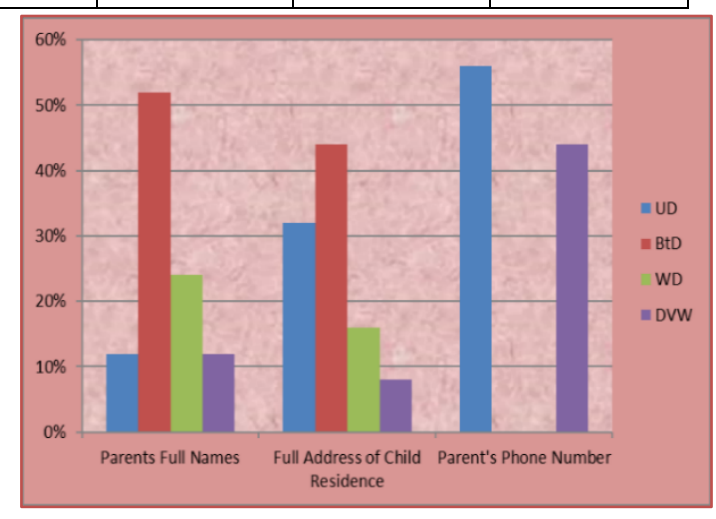

Figure 3. Child's Memory Diagram in First Cycle

The child's memory achievement has not yet reached the expected number of percentages so the research is continued in cycle II.

\section{Cycle II}

This following is the table which can be drawn the improvement of child's memory in cycle 2 as the result of the use of singing method.

Table 5. Child Memory Pre Cycle Data

\begin{tabular}{|l|c|c|c|c|}
\hline \multicolumn{1}{|c|}{ Memory Indicator } & UD & BtD & WD & DVW \\
\hline Parents' Full Names & 0 & 4 & 13 & 8 \\
\hline Percentage & $0 \%$ & $16 \%$ & $52 \%$ & $32 \%$ \\
\hline Full address of Child Residence & 0 & 5 & 12 & 8 \\
\hline Percentage & $0 \%$ & $20 \%$ & $48 \%$ & $32 \%$ \\
\hline Parent's Phone Number & 6 & 0 & 0 & 19 \\
\hline Percentage & $24 \%$ & $0 \%$ & $0 \%$ & $76 \%$ \\
\hline
\end{tabular}

The child's memory of the full name of his developed category and developing very well parents who reached the well-developed category reaches $80 \%$. While the child's memory of the and developed very well $84 \%$. Memory of the telephone numbers of parents who developed with complete address of a child's residence with a well- the category of well developed and developed very 
well reached $76 \%$. The child's memory in cycle 2 was drawn in this diagram as follows:

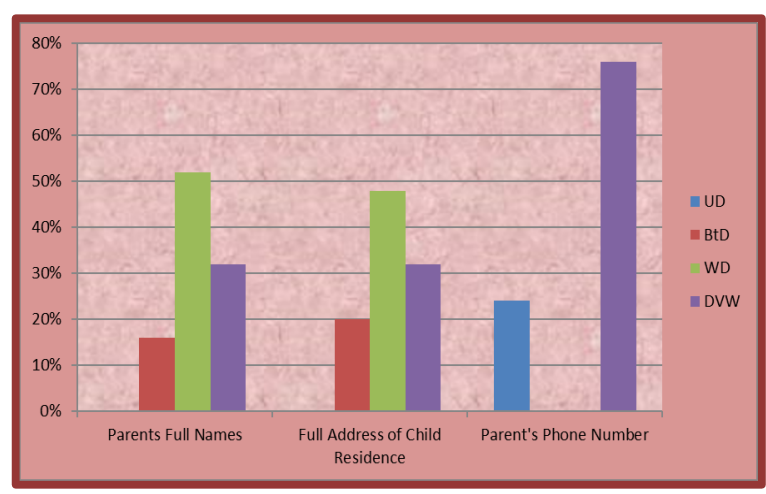

Figure 4. Child's Memory Diagram in Second Cycle

The achievement of the child's memory in welldevelop and verywell-develop are improved from $36 \%$ become $80 \%$. The improvement of child's memory from pre cycle until cycle 2 was drawn through this graphic as figure 5 .

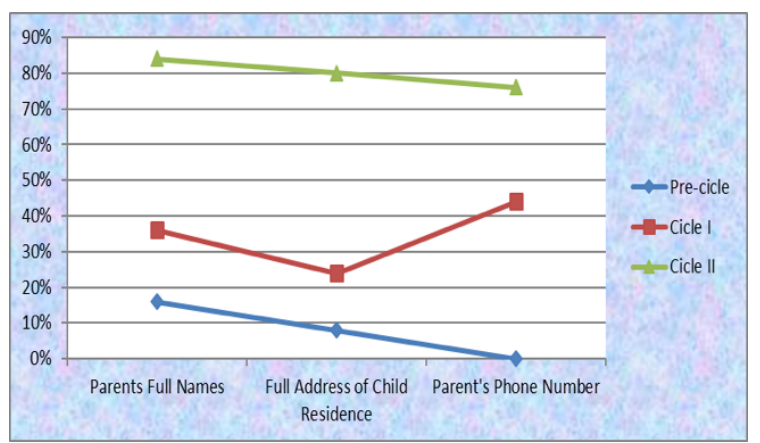

Figure 5. The improvement of child's memory from pre cycle until cycle

\section{Discussion}

Child memory preliminary data represents that the child has difficulty remembering important information about the full name of the parent, the full address of the place of residence and the telephone number of the parent. There were $16 \%$ (4 people) of children who were able to name their parents in a complete and straightforward manner. Two of the four children were children who were able to say the address of the house where they lived very well. This ability is obtained from the parenting style instilled by his parents. The parents of the six children have an awareness of the importance of instilling knowledge about fundamental identity in children. One parent instilled this important information by repeating it even in a non-serious environment. For example, when parents put on their children's school clothes while saying: "Dino (pseudonym) is Frans Imran Sihombing's child". The repeated words are stored in the child's memory. Based on the results of the conversation of the researcher towards one of the parents of the child who knew his home address completely. Information was obtained that the child was usually picked up by his mother in a pedicab public vehicle. The child often hears the address mentioned by his mother when transacting with a pedicab driver. It can be concluded that the child's memory is formed due to repetitive patterns.

Actions carried out through the application of singing methods to develop children's memory in the first cycle to the second cycle occur a high increase in leaps. This shows that the singing method which in its application is able to please children, builds a happy and cheerful soul which influences the brain's performance in storing memorable things for the child. Harianti (2008: 17) states: "Information that is combined with rhythm will be more remembered by the brain, because one of the principles of memory is rhythmic". In this study there were 6 children (24\%) who could not remember the telephone number of their parents. Many things set the background for this. Some factors include health 
factors, age factors, factors of interest $\&$ motivation, and genetic factors.

\section{CONCLUSION}

Children's memory of the full name of their parents with a well-developed category and developing very well from the first cycle to the second cycle increased from $36 \%$ to $84 \%$. The child's memory of the complete address of the residence with the category of developing well and developing very well from the first cycle to the second cycle increased from $24 \%$ to $80 \%$. Meanwhile, children's memory of their parents' telephone numbers with a well-developed category and developing very well from the first cycle to the second cycle increased from $44 \%$ to $76 \%$. There is an increase of $36 \%$, so that the average overall indicator of memory of children that is developing well and developing very well reaches $80 \%$. It can be concluded that the singing method can improve the memory of children aged 5-6 years in the kindergarten of Insan Pandhega.

\section{REFERENCES}

Carter, Kenneth \& Colleen M.Seifert. 2018. Psikologi Umum. Jakarta: Penerbit Buku Kedokteran EGC. Bharadia. Raksha. 2013. Roots \& Wings 3. India: Rupa Publicatoin.

Hapsari, Iriani Indri. 2016. Psikologi Perkembangan Anak. Jakarta: Indeks

Laksana, Hari. 2015. Bikin Ingatanmu Setajam Silet dengan Senam Otak. Yogyakarta: Araska.
Olivia, Femi. 2007. Membantu Anak Punya Ingatan Super. Jakarta: Elex Media Komputindo. 2011. Good Memory Building. Jakarta: Elex Media Komputindo.

Risaldy, Sabil. 2014. Bermain, Bercerita \& Bernyanyi. Jakarta Timur: PT Luxima Metro Media.

Santrock, John W. 2007. Psikologi Pendidikan. Jakarta: Kencana Pranada Media Group.

Sarwono W. 2012. Pengantar Psikologi Umum. Jakarta: PT Raja Grafindo Persada.

Seefeldt, Carol. dkk. 2008. Pendidikan Anak Usia Dini. Jakarta: PT Indeks

Semiawan, Conny.R. 2017. Strategi Pengembangan Otak. Jakarta: Elex Media Komputindo.

Sujiono, Yuliani Nuraini. dkk. 2009. Bermain Kreatif Berbasis Kecerdasan Jamak. Jakarta: PT Indeks.

Sujiono, Yuliani Nurani. 2009. Konsep Dasar Pendidikan Anak Usia Dini. Jakarta Barat: PT Indeks.

Tan, Oon-Seng \& Alice Seok-Hoon Seng (2005). Enhancing Cognitive Functions. Singapore: McGraw-Hill Education

Widiastuti. 2017. Modul SeniMusik. Universitas Muslim Nusantara.

Widyastuti, Andini.2016. Seabrek Kesalahan Guru PAUD yang Sering Diremehkan. Bandung: Diva Press.

Wijanarko, Jarot\& Ester Setiawati. 1998. Maksimalkan Otak Anak Anda. Jakarta: Keluarga Indonesia Bahagia. 